\title{
Utilization of Absorbed Nitrogen in Oxidized-Ammoniated Rice Straw and Rice Hulls by Rumen Microbes
}

\author{
Yoshiaki Terashima, Kenji Iwata and Hiroshi IтoH \\ Faculty of Animal Science, Kitasato University, \\ Towada-shi 034
}

(Received September 22, 1980)

Chemical treatment with ammonia or both sodium chlorite and ammonia for rice straw and rice hulls markedly increases nitrogen content ${ }^{11}$ and improves the palatability and digestibility of these roughages by sheep ${ }^{2}$. It has been shown in our previous reports ${ }^{3,4)}$ that the hot water insoluble nitrogen as well as non-protein nitrogen was increased by ammonia treatment and that the nitrogen content in fibrous materials was also increased. These results indicate that the increased nitrogen by the treatment exists as various nitrogen compounds and are retained at different place in roughages. The adsorbed nitrogen in low quality roughages originated from added ammonia may be utilized by rumen microbes for the synthesis of protein and subsequently stimulate rumen microbial growth. However, there is no information in this regard.

The present experiment was conducted to determine the effects of oxidized-ammoniated rice straw and rice hulls on ruminal activity as assessed by rates of the microbial protein synthesis and the adsorbed nitrogen incorporation, using rice straw and rice hulls treated with ${ }^{15} \mathrm{~N}$ labeled ammonia.

\section{Materials and Methods}

Rice straw (RS) and rice hulls ( $\mathrm{RH}$ ) were mixed with $50 \%$ water of air dry matter and than simultaneously treated with 0,5 or $25 \%$ sodium chlorite $\left(\mathrm{NaClO}_{2}\right.$, by wt.) and $5 \%$ ammonia $\left(\mathrm{NH}_{3}\right.$, by wt.) containing 10.4 atom $\%{ }^{15} \mathrm{~N}$, at $45^{\circ} \mathrm{C}$ for 3 days. After removing excess ammonia by aerating for a few days, they were ground to pass the $1 \mathrm{~mm}$ screen in a Wiley mill. The treatments of $\mathrm{NaClO}_{2}$ and $\mathrm{NH}_{3}$ for $\mathrm{RS}$ and $\mathrm{RH}$ are detailed in another paper ${ }^{5}$.

In vitro fermentation experiments were conducted using a $50 \mathrm{~m} l$ glass tube equipped with Bunsen valve top, to measure the microbial protein synthesis and incorporation of the adsorbed nitrogen into rumen microbes. About $0.5 \mathrm{~g}$ of sample was added

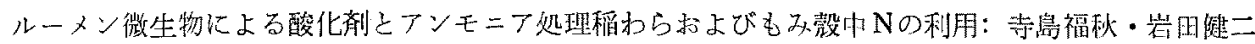

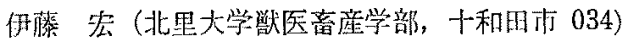


as the substrate to each fermentation vessel containing $20 \mathrm{ml}$ JoHnSon's artificial saliva ${ }^{6)}$ and $10 \mathrm{~m} l$ rumen inoculum. Rumen fluid was obtained immediately prior to feeding from a fistulated sheep fed orchardgrass hay once daily and was strained through four layers of cheesecloth for inoculum. Fermentation trials were carried out in a water bath at $39^{\circ} \mathrm{C}$ for 24 hours. At the end of fermentation, the tube was placed in an ice water to stop the fermentation. The culture medium was then strained through four layers of cheesecloth, and the filtrate was analyzed for microbial protein nitrogen. Microbial protein was determined by sodium tungstate precipitation reported by Schultz and Schult $z^{7}$. The ${ }^{15} \mathrm{~N}$ concentration of the nitrogen was determined by the use of ${ }^{15} \mathrm{~N}$ analyzer (NIA-1, Japan Spectroscopic Co. Ltd). The data were subjected to analysis of variance and means were compared using Duncan's multiple range test ${ }^{8)}$.

\section{Results and Discussion}

The incubation medium contained 88.6 and $19.8 \mathrm{mg}$ per $100 \mathrm{~m} l$ for total nitrogen and microbial protein nitrogen, respectively. Therefore, the $68.8 \mathrm{mg}$ nitrogen except microbial nitrogen was to be available for the microbial protein synthesis. The amounts of nitrogen of microbial protein synthesized during the 24 hour incubation period was estimated by subtracting the initial value from the final value of incubation.

The microbial nitrogen contents of the treated sample were significantly higher than those of both original materials as shown in Table, suggesting that the ammoniated materials stimulated the rumen microbial activity. The values in RH were significantly increased as a function of the level of $\mathrm{NaClO}_{2}$, but the value in RS treated with $25 \% \mathrm{NaClO}_{2}$ was significantly lower than that in the 0 and $5 \% \mathrm{NaClO}_{2}$ treated

7able 1. Microbial $N$ synthesized during the 24 hour incubation period from the adsorbed $\mathrm{N}$ of rice straw and rice hulls treated with ammonia or sodium chlorite and ammonia

\begin{tabular}{|c|c|c|c|c|c|c|c|c|}
\hline \multirow{3}{*}{$\begin{array}{c}\text { Treatment }(\%, w / w)^{1)} \\
\mathrm{NH}_{3} \\
\mathrm{NaClO}_{2}\end{array}$} & \multicolumn{4}{|c|}{ Rice straw } & \multicolumn{4}{|c|}{ Rice hulls } \\
\hline & 0 & 5 & 5 & 5 & 0 & 5 & 5 & 5 \\
\hline & 0 & 0 & 5 & 25 & 0 & 0 & 5 & 25 \\
\hline $\begin{array}{l}\text { Total } N \text { added as substrate } \\
\quad(\mathrm{mg} / 100 \mathrm{~m} l)\end{array}$ & 8.5 & 28.5 & 31.1 & 33.8 & 7.5 & 24.2 & 27.6 & 27.6 \\
\hline Microbial $\mathrm{N}(\mathrm{mg} / 100 \mathrm{~m} l)$ & $\begin{array}{l}27.7^{c} \\
\pm 2.1\end{array}$ & $\begin{array}{r}42.5^{a} \\
\pm 4.8\end{array}$ & $\begin{aligned} & 45.8^{\mathrm{a}} \\
& \pm 1.3\end{aligned}$ & $\begin{array}{l}34.5^{b} \\
\pm 0.8\end{array}$ & $\begin{array}{l}24.2^{\mathbf{c}} \\
\pm 1.2\end{array}$ & $\begin{array}{l}27.2^{\mathrm{bc}} \\
\pm 0.8\end{array}$ & $\begin{array}{l}28.7^{b} \\
\pm 0.9\end{array}$ & $\begin{aligned} & 34.0^{8} \\
\pm & 3.8\end{aligned}$ \\
\hline $\begin{array}{l}\text { The synthesized microbial } \\
\mathrm{N} \text { during incubation } \\
\text { period }(\mathrm{mg} / 100 \mathrm{ml})^{2 !}\end{array}$ & 7.9 & 22.7 & 26.0 & 14.7 & 4. 4 & 7.4 & 8.9 & 14.2 \\
\hline $\begin{array}{l}\text { Microbial } \mathrm{N} \text { derived from } \\
\text { the adsorbed } \mathrm{N}(\mathrm{mg} / 100 \mathrm{~m} l) \\
(\% \text { of sythesized } \mathrm{N})\end{array}$ & s) & $\begin{array}{r}5.5^{b} \\
\pm 0.6 \\
(24)\end{array}$ & $\begin{array}{r}7.0^{\mathrm{a}} \\
\pm 0.2 \\
(27)\end{array}$ & $\begin{array}{r}5.0^{b} \\
\pm 0.1 \\
(34)\end{array}$ & & $\begin{array}{r}1.5^{c} \\
\pm 0.1 \\
(20)\end{array}$ & $\begin{array}{r}2.2^{\mathrm{b}} \\
\pm 0.1 \\
(25)\end{array}$ & $\begin{array}{r}4.8^{a} \\
\pm 0.6 \\
(34)\end{array}$ \\
\hline
\end{tabular}

1) Air dry matter basis. 2) These values were estimated by subtracting the blank value $(19.8 \mathrm{mg} / 100 \mathrm{~m} l)$ from that of each substrate. 3) Microbial $\mathrm{N}$ derived from the adsorbed $\mathrm{N}(\mathrm{mg})=$ Total microbial $\mathrm{N}(\mathrm{mg}) \times \frac{{ }^{15} \mathrm{~N} \text { atom } \% \text { excess in microbial } \mathrm{N}}{{ }^{15} \mathrm{~N} \text { atom } \% \text { excess in added } \mathrm{NH}_{3}}$. Means in the same line with different superscripts differ significantly. $(\mathrm{P}<0.05$, means of 3 estimates $上 \mathrm{SD})$ 
ones. Further work is required to explain this discrepancy, although the higher level of $\mathrm{NaClO}_{2}(25 \%)$ to treatment would be appear to give a detrimental effect on microbial activity. The stimulated effect of oxidized-ammoniated roughages on the synthesis of microbial protein would be due to the increases of available energy and nitrogen sources.

The microbial nitrogen derived from the adsorbed nitrogen was calculated by total microbial nitrogen content and ${ }^{15} \mathrm{~N}$ concentration of microbial and added ammonia nitrogen as shown in Table. The value in the ammoniated RS treated with 0,5 and $25 \%$ of $\mathrm{NaClO}_{2}$ was $5.5,7.0$ and $5.0 \mathrm{mg} / 100 \mathrm{ml}$ and $1.5,2.2$ and $4.8 \mathrm{mg}$ in $\mathrm{RH}$, respectively. These values in $\mathrm{RH}$ were significantly increased as the level of $\mathrm{NaClO}_{2}$ increased. The values observed in $\mathrm{RS}$ treated with 0 and $25 \% \mathrm{NaClO}_{2}$ were similar and they were significantly lower than that of $5 \% \mathrm{NaClO}_{2}$ treated RS.

The rates of the microbial protein nitrogen derived from the adsorbed nitrogen to the total nitrogen of microbial protein synthesized during the incubation ranged from $24 \%$ to $34 \%$ for $\mathrm{RS}$ and from $20 \%$ to $34 \%$ for $\mathrm{RH}$. These results indicated that the adsorbed nitrogen originated from added ammonia in roughages was certainly utilized by rumen microbes as well as other nitrogen sources.

This work was supported in part by Grant 348068 from the Ministry of Education, Science and Culture, Japan.

\section{References}

1) Terashima, Y., I. Torisu and H. Iroh, Jpn. J. Zootech. Sci., 51: 40-47, 1980.

2) Terashima, Y., H. Harada, M. Tarun and H. Itoh, Jpn. J. Zootech. Sci., 52: 269 274. 1981.

3) IToh, H., Y. Terashima, N. Tohrai and Y. Matsui, Jpn. J. Zootech. Sci, 46: 87-93. 1975.

4) Itoh, H., Y. Terashima and N. Tohrai, Jpn. J. Zootech. Sci., 50: 54-61. 1979.

5) Itoh, H., Y. Terashima, K. Ueda and Y. Takahashi, Jpn. J. Zootech. Sci., 52. 269-274. 1981.

6) Johnson, D. R., J. Anim. Sci., 25: 855-875. 1966.

7) Schultz, J.A. and E. Schultz, J. Dairy Sci., 53:781-784, 1970.

8) Duncan, D. B., Biometrics, 11: 1-42. 1955. 